Water Allocation Mechanisms

\section{Principles and Examples}

Ariel Dinar

Mark W. Rosegrant

Ruth Meinzen-Dick
What does it mean to treat water as an economic good?

What does it mean to

"allocate appropriately?"

The World Bank

Agriculture and Natural Resources Department

Sector Policy and Water Resources Division

and

International Food Policy Research Institute

June 1997 
Policy Research Working Paper 1779

\section{Summary findings}

From the earliest times, water resources have been allocated on the basis of social criteria - maintaining the community by ensuring that water is available for human consumption, for sanitation, and for food production. Societies have invested capital in infrastructure to maintain this allocation.

Yet social change, including changes in (and more understanding of) how goods are distributed, has produced new issues in water allocation. Population growth has made water scarcity a major problem in many countries and water pollution, while by no means a recent problem, is more widespread than ever before.

Traditionally the state has played a dominant role in managing water resources, but inefficient use of water, poor cost recovery for operating and maintenance expenses, the mounting cost of developing new water sources, and problems with the quality of service in agency-managed systems has led to a search for alternatives that make water allocation and management more efficient.

Dinar, Rosegrant, and Meinzen-Dick address some of the basic principles of treating water as an economic good and of allocating it among sectors. After outlining the economic principles behind allocating scarce water resources, they review the actual means of various mechanisms used for allocating water, including marginal cost pricing, social planning, user-based allocation, and water markets. Giving examples from experience in several countries, they weigh the pros and cons of different approaches to water allocation, showing that no single approach is suitable for all situations.

Clearly the state must play an important regulatory role, for example, but how effectively it does so depends on the relative political influence of various stakeholders and segments of society. User-based allocation is generally more flexible than state allocation, but collective action is not equally effective everywhere; it is most likely to emerge where there is strong demand for water and a history of cooperation. The outcome of market allocation depends on the economic value of water for various uses, but moving toward tradable property rights in water may ease the process of intersectoral reallocation by compensating the "losers" and creating incentives for efficient water use in all sectors.

This paper - a joint product of the Sector Policy and Water Resources Division, Agriculture and Natural Resources Department, and the International Food Policy Research Institute - is part of a larger effort implement the 1993 World Bank's Water Resources Management Policy. Copies of this paper are available free from the World Bank, $1818 \mathrm{H}$ Street NW, Washington, DC 20433. Please contact Michele Rigaud, room S8-258, telephone 202-473-0344, fax 202-522-3309, Internet address mrigaud@worldbank.org. June 1997. (41 pages)

The Policy Research Working Paper Series disseminates the findings of work in progress to encourage the exchange of ideas about development issues. An objective of the series is to get the findings out quickly, even if the presentations are less than fully polished. The papers carry the names of the authors and should be cited accordingly. The findings, interpretations, and canclusions expressed in this paper are entirely those of the authors. They do not necessarily represent the view of the World Bank, its Executive Directors, or the countries they represent. 


\title{
WATER ALLOCATION MECHANISMS- PRINCIPLES AND EXAMPLES
}

\author{
Ariel Dinar, ${ }^{1}$ Mark W. Rosegrant, and Ruth Meinzen-Dick ${ }^{2}$
}

\section{ACKNOWLEDGMENT}

The autors would like to acknowledge the very valuable comments provided by Mylène Kherallah, Stephen Mink, and Lesslie Small.

${ }^{1}$ World Bank, Agriculture and Natural Resources Department

IFPRI 



\section{TABLE OF CONTENTS}

INTRODUCTION 2

ECONOMIC PRINCIPLES OF SCARCE RESOURCE ALLOCATION

Economic Efficiency

4

Equity

4

Criteria for Allocation

4

WATER ALLOCATION MECHANISMS

Marginal cost pricing

Advantages

Disadvantages

7

Public (Administrative) Water Allocation

Advantages

Disadvantages

Water Markets

Advantages

Disadvantages

14

User-Based Allocation

Disadvantages 
$\begin{array}{ll}\text { Marginal Cost Pricing } & 17\end{array}$

Irrigation water in France $\quad 17$

Household Consumption $\quad 19$

Industrial Water Use 19

$\begin{array}{ll}\text { Public Water Allocation } & 19\end{array}$

$\begin{array}{ll}\text { Bureau of Reclamation and the American West } & 20\end{array}$

$\begin{array}{ll}\text { The PASTEN Mechanism in Indonesia } & 21\end{array}$

Water Markets 22

Water Markets in Chile $\quad 22$

Drought Water (Market) Bank in California 23

Advanced Ground Water Markets in Gujarat India $\quad 24$

Latent Water Markets in Cumbum Valley, Periyar-Vaigai Basin, Tamil Nadu $\quad 24$

Transferable Water Entitlements In Australia $\quad 26$

Mixed Systems of Allocation $\quad 28$

California Groundwater $\quad 28$

User-Based Allocation 29

Balinese Subaks in Indonesia $\quad 29$

Tank Irrigation in India $\quad 30$

WUA Management of the Tank in Vengal Village, Tamil Nadu 31

Operational Rules in a Communal Irrigation System in Portugal 32

$\begin{array}{ll}\text { DISCUSSION } & 32\end{array}$

$\begin{array}{ll}\text { REFERENCES } & 36\end{array}$ 


\section{WATER ALLOCATION MECHANISMS-}

\section{PRINCIPLES AND EXAMPLES}

\section{INTRODUCTION}

Water resources provide important benefits to humankind, both commodity benefits and environmental values. Because of the increasing scarcity of water for both its commodity and environmental benefits and scarcity of the resources required to develop water, economic consideration plays an increasingly important role in public decisions on water projects, reallocation proposals and other water policies.

Water has traditionally been provided to meet demand with substantial involvement of governments. Allocation by governments, usually referred to as public allocation, has usually not addressed economic efficiency, but has been necessary because of several features that distinguish water from other scarce resources.

What is so unique about water? It has several characteristics that make the role of the public sector in its development and management more essential than for other goods that can be handled efficiently in a market framework. For example, some water services are public goods, that is, their provision to one individual does not eliminate other individuals from using it. The lack of beneficiary identification may cause under-investment, mis-allocation of the resource, and negative externality effects among the potential users, leading to market failure. Other services are characterized by economies of scale, that is, the average cost decreases as more units are produced. This may create monopolistic power and socially inefficient allocation, leading to market failure. Water projects are usually associated with large investment; most capital markets do not have the capacity to finance such huge investments over the necessary time period. Because of the range of market failures and the large volume of capital needed for water projects, a significant share of water-related infrastructure investments are conducted by the public sector (World Bank, 1993). In some cases, water allocation is used by governments to promote agrarian reforms, so that additional objectives, such as income redistribution, settlement of remote regions, or food security, enter the social welfare equation. There are other characteris- 
tics of water, such as its physical nature, which make it hard to transport and allocate, and the fact the it is a common pool resource, allowing several users to benefit from its consumption. For these reasons, public (government) allocation of water is still the main mechanism in many countries.

The objectives of water resources policy and the criteria for the allocation of water can be targeted via numerous forms of allocation, ranging from complete control by the government to a mixture of market and government allocation, to predominantly market allocation (even the latter, however, requires government support and intervention as explained above). Since countries and circumstances vary widely, allocation within any country can be regarded as a unique system for sharing the available water across the known sources of demand. The structure of any particular system of water allocation is of course influenced by the existing institutional and legal frameworks as well as the water resources infrastructure. Indeed, some forms of allocation are likely to require a specific set of laws and regulations, organizations, and water resources infrastructure to operate effectively. The major forms of allocation, however, are relatively few. This paper identifies several of them, together with their major advantages, and disadvantages, and provides examples of their use in various countries.

\section{ECONOMIC PRINCIPLES OF SCARCE RESOURCE} ALLOCATION

Water resources that comprise surface water (rivers, lakes, and reservoirs), groundwater, floodwater, and, with the advent of new technologies, desalinated water, are an essential input for various economic sectors, such as municipal, industrial, agricultural, hydropower, recreation and environmental. With increased population growth rates, improved life style, and dwindling supplies (both in terms of quantity and quality), the competition over scarce water resources is increasing. It is thus of increasing importance that the existing water resources be allocated more efficiently. It is therefore necessary to make economic decisions compatible with social objectives, that is efficiency and equity considerations. While economic efficiency is concerned with the amount of wealth that can be generated by a given resource base, equity deals with the distribution of the total wealth among the sectors and individuals of society. Many forms of water allocation schemes attempt to combine both efficiency and equity principles. 


\section{Economic Efficiency}

Allocation of water to different sectors can be viewed from a purely economic point of view as a portfolio of investment projects: water is the limited resource (capital), and the economic sectors use the capital and produce returns. In an economically efficient resource allocation, the marginal benefit from the use of the resource should be equal across sectors (that is, uses) in order to maximize social welfare. In other words, the benefit from using one additional unit of the resource in one sector should be the same as it is in any other sector. If not, society would benefit by allocating more water to the sector where the benefits, or returns, will be highest.

\section{Equity}

Resource allocation may also be based on equity. Equity objectives are particularly concerned with fairness of allocation across economically disparate groups, and may or may not be consistent with efficiency objectives. In the case of household water, for example, an equitable allocation of water resources suggests that all households, regardless of their ability to purchase water, still have a basic right to water services. Meeting this objective may entail providing government subsidies or free service, or perhaps adopting a differential pricing structure based on income.

\section{Criteria for Allocation}

Appropriate means of resource allocation are necessary to achieve optimal allocation of the resource. There are several criteria used to compare forms of water allocation (Howe et al. 1986):

- $\quad$ Flexibility in the allocation of supplies, so that the resource can be shifted from use to use, place to place, as demand changes, making it possible to equate marginal values over many uses with least cost.

- Security of tenure for established users, so that they will take necessary measures to use the resource efficiently; security does not conflict with flexibility as long as there is a reserve of the resource available to meet unexpected demands. 
- Real opportunity cost of providing the resource is paid by the users, so that other demand or externality effects are internalized. This allows the allocation to account for environmental uses with a non-market value (such as providing a habitat for wildlife). This also directs the employment of the resource to activities with the highest alternative values.

- Predictability of the outcome of the allocation process, so that the best allocation can be materialized and uncertainty (especially for transaction costs) is minimized.

- Equity of the allocation process should be perceived by the prospective users, providing equal opportunity gains from utilizing the resource to every potential user.

- Political and public acceptability, so that the allocation serves values and objectives, and is therefore, accepted by various segments in society.

These criteria, frequently invoked in many water policy debates on the need for equity or fairness in water allocation, and whether or not these criteria are relevant in the case of water. An additional set of criteria should include (Winpenny 1994):

- Efficacy, so that the form of allocation changes existing undesirable situation such as depletion of ground water, and water pollution, and drives towards achieving desired policy goals.

- Administrative feasibility and sustainibility, to be able to implement the allocation mechanism, and to allow a continuing and growing effect of the policy. 


\section{WATER ALLOCATION MECHANISMS}

This section discusses the concepts, advantages, and disadvantages of several water allocation mechanisms: marginal cost pricing, public allocation, water markets and user-based allocation.'

\section{Marginal cost pricing}

A marginal cost pricing (MCP) mechanism, in essence, targets a price for water to equal the marginal cost of supplying the last unit of that water. An allocation which equates water's unit price (the marginal value of water) with the marginal cost is considered an economically efficient, or socially optimal, allocation of water resources. The efficiency criterion maximizes the total value of production across all affected sectors of the economy.

Water supply charges typically include collection, transport to a treatment plant, water treatment to meet quality standards, distribution to customers (Spulber and Sabbaghi 1994), and monitoring and enforcement. Water charges typically do not include headworks, which should be included. $^{2}$ Water charges may also include any social costs (or benefits), although they may be more difficult to calculate. ${ }^{3}$ If there are higher costs to allocate water to some uses than to others, then the price can be differentiated to be equivalent to the relevant marginal cost of provision to each type of use (Tietenberg 1988: 206; Spulber and Sabbaghi 1994). Although water may have a scarcity value, which depends on location and time, it might not always be reflected in the cost of the water consumers are faced with. The two concepts-social cost and scarcity value - are reflected in higher MC curves then the private MC curve. MCP can be applied also to develop differential prices for different qualities of water where higher-quality water has a higher marginal cost of provision (Spulber and Sabbaghi 1994: 224). In the same

\footnotetext{
${ }^{1}$ While Meinzen-Dick and Mendoza (1996) include (volumetric) water pricing among public allocation mechanisms, this paper distinguishes Marginal Cost Pricing from all other pricing schemes since most public allocation mechanisms are quota-oriented, or if prices are introduced, they intend to recover costs and are mainly based on average cost pricing.

${ }^{2}$ The question of allocating costs of multi-use headworks among economic activities has been discussed and used in the literatutre. Allocation methods used include: proportional allocation, Separable Cost Remaining Benefit, marginal cost allocation, and game theory allocation methods. This issue is beyond this paper's objective. However, the interested reader can find adequate information in Biddle and Steinberg (1984).

${ }^{3}$ For example, farmers using treated wastewater for irrigation, may be providing society with a disposal option and treatment level that is cheaper than the next best option. Farmers may thus be providing an environmental service, and the price they pay for the treated water should reflect this.
} 
way, reliability of supply is an important factor where higher marginal cost are associated with higher level of reliability.

\section{Advantages}

The most obvious advantage of MCP is that it is theoretically efficient. Not only are the marginal costs and benefits equal, but at the efficient price the difference between the total value of water supplied and the total cost is at a maximum. MCP avoids the tendency to under-price (and consequently overuse) water. Under conditions of scarcity, excessive water use is obviously undesirable and comes at a high social cost. A MCP system could avert overuse because prices would rise to reflect the relative scarcity of water supplied. MCP approaches to water allocation can also be combined with pollution charges or taxes so that the externalities in use of water are embedded in the incentives facing the water user.

\section{Disadvantages}

One of the principle limitation of MCP relates to difficulties in defining marginal cost itself (Saunders et. al 1977). These difficulties are in part a result of problems in collecting sufficient information to correctly estimate and subsequently monitor benefits and costs. Spulber and Sabbaghi (1994) note the following definition problems:

- The marginal cost is multi-dimensional in nature, that is it includes several inputs, such as water quantity and quality.

- The marginal cost varies with the period over which it is measured, that is short-run vs. long-run marginal cost.

- The marginal cost varies depending upon whether a demand increment is permanent or temporary. That is, the composition of fixed and variable costs as determined by short and long-term demand has a significant impact on the marginal cost. 
These issues, among others, create considerable difficulties in selecting a short-run (SRMC) or long-run marginal cost (LRMC) figure for establishing price. Simply put, when existing supply is fully utilized, water providers must invest huge sums in developing further capacity. If MCP is strictly applied, then the high cost of expanding water supply (new reservoirs and pipes, for example) results in a "bump" in the marginal cost function of the water provider which stabilizes only after the recovery of the large fixed costs.

MCP is also disadvantageous because it tends to neglect equity issues. In periods of shortage or scarcity, if prices increase to the necessary level, lower income groups may be negatively affected. Equity considerations need to be addressed when marginal costs push water prices beyond what lower income groups can afford, and if those who invested earlier have to pay more when new users are added.

At a more practical level, MCP is difficult to implement because it requires volumetric monitoring, which is very costly and difficult to administer. Also, MCP concepts are frequently poorly understood by those involved in policymaking and administration (United Nations 1980). Moreover, the information requirements for an efficient system of administered prices are demanding and much of this information would necessarily be gathered by trial-and-error experimentation (Phelps, Moore and Graubard, 1978). Information is expensive and mistakes made in the trial-and-error process may be costly. If prices are set too low, demand for water would be excessive, and if prices are set too high, water would be wasted to drainage.

\section{Public (Administrative) Water Allocation}

As mentioned before, three main points support the argument for public or government intervention in the development and allocation of water resources: it is difficult to treat water like most market goods, water is broadly perceived as a public good, and large-scale water development is generally too expensive for the private sector.

Public allocation is seen in the majority of large-scale irrigation systems, where the state decides what water resources can be used by the system as a whole, and allocates and distributes water within different parts of the system. Public allocation of water has usually been associated with water quantities, based on physical norms and political influence. Although the state allocation usually applies only at the trunk and distributary level of irrigation systems, in systems 
with pukka warabandi rotation in Pakistan and India, the agency even specifies the particular times and places individual farmers are entitled to water.

In the domestic water sector, both municipal water supply corporations and many rural water supply and sanitation programs represent public allocation mechanisms. Public allocation also dominates industrial water uses through the granting of permits and regulation of water withdrawal and effluent discharge by individual companies and industries. Although hydropower is a non-consumptive use, it requires public water allocation through decisions to build dams and the operating rules that change the flow patterns of rivers. Public allocation to fisheries, wildlife, and navigation are embodied in restrictions on the development or withdrawal of water for other uses.

The state's role is particularly strong in inter-sectoral allocation, as the state is often the only institution that includes all users of water resources, and has jurisdiction over all sectors of water use. This is particularly true in South Africa, as the new government attempts to bridge the gulf between white and black farmers, wealthy suburbs with subsidized water supplies and 12 million blacks without potable water, as well as between domestic, agricultural, industrial, mining, and wildlife sectors. ${ }^{4}$ Thus, the Water Law Review Panel (Republic of South Africa 1996:14) sets out the principle that:

"The national government is the custodian of the nation's water resources, as an indivisible national asset, and has ultimate responsibility for, and authority over, water resource management, the equitable allocation and usage of water, the transfer of water between catchments and international water matters".

Many countries adhere to some form of Public Trust Doctrine, that maintains that the state holds navigable waters and certain other water resources as an aspect of sovereignty. Because these are held as common heritage for the benefit of the people, the state cannot alienate such ownership of the basic resource and concomitant responsibility (Koehler 1995). This argument has been used in both the United States and India as a basis for environmental protection (Moench 1995)--re-asserting the state's role in allocating water between agricultural, industrial, municipal, and environmental sectors.

\footnotetext{
${ }^{4}$ The case of Orange Free State in South Africa, is a particularly relevant. An action program for the creation of sustainable livelihoods in the rural and peri-urban economy via reallocation of existing water quantities among landless inhabitants and rich farmers, is discussed (Free State Province, 1997)
} 


\section{Advantages}

Public allocation intends to promote equity objectives, that is, ensuring water supply to areas of insufficient quantity. It can protect the poor, sustain environmental needs, and provide a given level of water to meet minimal needs in the receiving sector. The physical allocation of water among the users is independent of the charge. Allocation rules in this case can be based on historical facts (such as prior rights), on equal shares in available water volumes, on individual requirements, or even based on political pressure.

The list in Box 1 details the characteristics of water that establish a role for government intervention and action in water allocation.

\section{Box 1: The Case for Government Involvement in Water Management.}

Water has several distinguishing features that can define a role for public action:

1. Large, lumpy capital requirements and economies of scale in water infrastructure tend to create natural monopolies, warranting regulation to prevent overpricing. Moreover, many water investments produce joint products, such as recreation, electric power, flood control, and irrigation, which make pricing and allocation decisions difficult.

2. The large size and extremely long time horizons of some investments, given underdeveloped capital markets and the potential for political interference in many water infrastructure investments, reduce incentives for private investments in the sector.

3. The uses of water within a river basin or aquifer are interdependent. Withdrawals in one part of the basin reduce the availability of water for other users; groundwater pumping by one user may lower the water table and increase pumping costs for all users; and pollution by one user affects others in the basin, especially those located downstream. These interdependencies suggest that having all users agree to the rules of the game--or lacking that, imposing government regulations, taxes, or both-could improve the social value of water resources.

4. Certain aspects of water activities, such as the control of floods and waterborne diseases, are (local) public goods, which cannot easily be charged for on the basis of individual use. In such cases, public initiative may be required to ensure that levels of investment are appropriate.

5. Water resources are often developed because of their strategic importance for national security and for regional development. Governments thus typically maintain ownership of water thoroughfares, providing services such as the coast guard and traffic regulation. Some regions are subject to periodic droughts. Because water is essential to sustaining life, governments may take control of water.

Source: World Bank 1993.

Box 1 states clearly that there is no single objective to a public water allocation mechanism. Although a national or state agency may consider MCP approach, public water allocation mechanisms are far more likely to be preoccupied with equity, sovereignty, and an overwhelm- 
ing concern with satisfying the greater public good. Ideally, these objectives and the efficiency objectives produced by MCP would be met simultaneously.

\section{Disadvantages}

Supplying water to deficient areas leads to expensive, publicly financed water projects which preclude any need to purchase water rights based upon the scarcity of the resource. In other words, subsidized water supply development replaces market mechanisms of water supply via transfers of water titles. Prices, as a result, do not represent either the cost of water supply or its value to the user. Publicly-mandated penalties on misuse of the water quota can fail to incorporate the value of numerous goods and services which are either difficult to price or are not bought and sold.

As a result, public allocation mechanisms often lead to waste and mis-allocation of water, as well as fragmented investment and management of the existing resource. Also, public allocation often does not support user participation. In many cases, these results contradict the original policy goals in the basis of the public intervention. Namely, social objectives are not fulfilled.

Public allocation or regulation is clearly necessary at some levels, particularly for intersectoral allocation. However, problems with this form of allocation are seen in poor performance of government-operated irrigation systems, leaking municipal water supply systems operated by public utilities, licensing irregularities and inadequate controls over industrial water use, and damage to fish and wildlife habitats.

Meinzen-Dick and Mendoza (1996) point out that a major reason for such problems lies in the failure of the public allocation mechanism to create incentives for water users to conserve water and improve use efficiency. Under public management the dominant incentive to comply is coercion; that is, setting regulations and using sanctions for those who break them. But this type of incentive is only effective if the state detects infractions and imposes penalties. In many cases the state lacks the local information and ability to penalize, e.g. for breaking water delivery structures or for excessive water withdrawals. It is relatively more effective where there are fewer points to monitor; for example, main canals of large irrigation systems rather than tertiary delivery structures or small-scale irrigation, or withdrawal and discharge points for a few large factories rather than for many small business enterprises. 
Furthermore, most implementing agencies dealing with water resources have only sectoral responsibility (e.g. to deal with irrigation or drinking water or industry or environment). While the state as a whole has responsibility for overall water use, the executing agencies have neither mandate nor incentive to create integrated projects or to balance the needs of various users (Yoder 1981). ${ }^{5}$ Thus, the agencies operate within strict limits on the quantity of water use, or respond only to single constituencies (e.g. farmers, industrialists). This provides very little flexibility to respond to changing patterns of water demand, and the decision-making mechanisms for inter-sectoral allocation are either unclear or highly politicized. In practice, public water allocation mechanisms typically consist of various inefficient water pricing schemes. Flatrates/fixed charges are common, easy to manage and easy for users to understand. Other rate schedules are often based either upon a minimum charge or a fixed charge. These charges are often accompanied by either volume charges, seasonal rates, or an increasing or decreasing block rate.

The structures of fees for water use under pubic allocation often do not create incentives for the users themselves to save water and use it more efficiently. The vast majority of irrigation systems, and even many domestic water supply systems, charge a flat rate per hectare or household served. Under this type of fee, not only do the users not pay according to the amount of water consumed by that land or that household, but increasing the water charges-a simplistic solution too often suggested to improve water use efficiency-can even have a perverse effect of increasing water consumption as people feel that they are entitled to more water because they are paying more.

\section{Water Markets}

In the following discussion, a market-based allocation of water is referred to as an exchange of water-use rights, compared to a temporary exchange of a given quantity of water between neighboring users. The latter is called a spot water market, and operates some times under different set of rules than a market for water-use rights.

From a strict economic point of view, the operation of a (competitive) market has several conditions. First, the market should have many identical sellers and buyers, each with complete

\footnotetext{
${ }^{5}$ There are several exceptions such as the widening role of the various departments of Commission $\mathrm{Na}$ tional del Agua-CNA in Mexico (Cummings et al. 1996), and of (Water and Power Development Authority) WPDA's water wing in Pakistan (World Bank 1996).
} 
information on the market rules (institutions), and each facing similar transaction costs. Second, decisions made by each seller or buyer are independent of decisions made by other sellers and buyers. Third, decisions made by one individual should not affect the outcome of another individual. And, finally, the individuals (or economic agents operating in a competitive market) are motivated to maximize their profits. Under such conditions, demand and supply forces dictate the quantities to be traded and the unit price for the commodity in this market.

Usually, commodities (resources) will move from their uses at low value to highest values. Therefore, market-based allocation is considered economically efficient from an individual and social point of view.

In the case of water, there are several additional stipulations resulting from the special characteristics of water that have been discussed earlier. Sometimes it requires intervention of government to create necessary conditions for markets to operate. This includes (1) defining the original allocation of water rights, (2) creating the institutional and legal frameworks for trade, and (3) investing in basic necessary infrastructure to allow water transfers. For more details see Holden and Thobani (1995).

The market mechanism, if operated under such conditions, could secure water supply for high-value uses in various sectors without the need to develop new, costly water resources. Also, by allowing compensation for water sold by low-value uses, water markets provide an incentive for more efficient water use.

\section{Advantages}

Water markets provide several benefits. The seller has an opportunity under certain conditions to increase profitability (except if all water resources are sold and the seller ceases economic activity). The buyer benefits because the water market encourages increasing water availability. In the case of water trade between the agriculture and the urban sectors, the environment may benefit in two ways. First, the water market induces a shift towards improved water management and efficiency in agriculture, reducing irrigation-water-related pollution. Second, with the water market, farmers may afford to internalize externality cost, or even pay higher pollution-related social cost.

Rosegrant and Binswanger (1994) enumerate the following potential benefits of water markets. The first benefit is empowerment of water users by requiring their consent to any 
reallocation of water and compensation for any water transferred. The second is to provide security of water rights tenure to the water users. If well-defined rights are established, the water users can invest in water-saving technology knowing that they will benefit from the investment. Third, a system of marketable rights to water would induce water users to consider the full opportunity cost of water, including its value in alternative uses, thus providing incentives to efficiently use water and to gain additional income through the sale of saved water. Fourth, a system of tradable water rights will provide incentives for water users to take account of the external costs imposed by their water use, reducing the pressure to degrade resources. Fifth, compared to the often-recommended volumetric pricing of irrigation water, the rights-based approach would be more acceptable to farmers. Imposition of volumetric pricing wullit be seen by farmers as expropriation of traditional water rights, which would create capital losses in established irrigated farms. Establishment of transferable water rights would instead formalize existing rights to water.

Finally, allocation of water through tradable rights provides maximum flexibility in responding to changes in crop prices and water values as demand patterns and comparative advantage change and diversification of cropping proceeds. The market-based system is more responsive than centralized allocation of water.

\section{Disadvantages}

Several unique characteristics of water present special challenges in the design of a wellfunctioning water market. A list of these difficulties include: measuring water, defining water rights when flows are variable, enforcing withdrawal rules, investing in necessary conveyance systems, sale of water-for-cash by poor farmers, and finally, externality and third party effects and environmental degradation: A transfer of water from agriculture to urban use may reduce return flows, which may affect a third party. In addition, increased industrial and urban water use may create extensive environmental pollution if necessary measures to limit industrial and municipal untreated sewerage disposal are not introduced.

Effective market allocation requires that third-party effects of water trades can be identified and accurately quantified, and the associated costs are fully taken into account in the exchange process. The pervasiveness of externalities such as changes in downstream and return flows, pollution, overdraft of water tables, waterlogging, and other adverse, often irreversible environmental effects, provides the fundamental argument against markets. From the economic 
efficiency viewpoint, these externalities should be considered in the cost of the transfers. From the equity viewpoint, compensation for these third party effects should be paid to those who have been harmed as a result of the agreement.

Perhaps even more important, in existing irrigation systems, the value of prevailing usefructuary water rights (formal or informal) has already been capitalized into the value of irrigated land. Imposition of administered pricing is correctly perceived by rights holders as expropriation of those rights, which would create capital losses in established irrigation farms (Rosegrant and Binswanger, 1994). Attempts to establish administered efficiency prices are thus met with strong opposition from established irrigators, which makes it difficult to institute and maintain an efficiency-oriented system of administered prices (Randall, 1981).

\section{User-Based Allocation}

Farmer-managed irrigation systems provide one of the clearest examples of user-based water allocation. Studies have shown a wide variation of rules for allocation within such systems; by timed rotation, depth of water, area of land, or shares of the flow (Yoder 1994). In the domestic water supply sector, user-based allocation is seen in community wells and hand pump systems, as well as in a growing number of more complicated systems managed by water and sanitation associations (Watson et al. 1994). Inter-sectoral allocation by users is seen in the management of village tanks (ponds) or other local water sources used for domestic water, irrigation, and even animal watering.

User-based allocation requires collective action institutions with authority to make decisions on water rights. While empirical studies of common pool resource management (including water) have shown that such institutions can develop spontaneously or through an external catalyst, the institutions are not always in place or strong enough to allocate water efficiently (see Meinzen-Dick et al, 1997). A wide range of factors affect the viability of organizations for water management, but Coward (1986:227) argues that property rights are a critical factor. The creation and ownership of irrigation property--including water, conveyance structures, and pumping equipment--form the basis for relationships among the irrigators, which "become the social basis for collective action by irrigators in performing various irrigation tasks." The cohesive force of property is important in many aspects of water management, but it 
is especially critical for allocation. User groups cannot make decisions regarding water if they have no rights--de facto or de jure--over that water (Meinzen-Dick and Mendoza 1996).

The effect of user-based allocation on water conservation depends on the content of local norms and the strength of local institutions. It is easier for users to organize collective action for increasing their water supply (which represents a positive-sum activity for the membership) than for distributing the water amongst themselves (which is at best a zero-sum activity). If the organization does not actively promote efficient use, this allocation mechanism will have little effect in demand management. However, social norms can create incentives for conservation, particularly if they are backed up by rules against excess consumption, monitoring of compliance, and sanctions against water waste. Where members of water management organizations are conscious of the need to conserve, watch each others' water use patterns, and trust that if they save water, others will do likewise so that all contribute to the common good, user-based allocation can achieve high efficiency in water use.

\section{Advantages}

A major advantage of user allocation is the potential flexibility to adapt water delivery patterns to meet local needs. Because those directly involved in water use--either for agriculture, home consumption, or industry--have more information on local conditions than the agency staff possesses, they do not have to rely on rigid formulas for allocation. For example, certain fields may be given more water than others, based on the water retention capacity of the soils. User organizations may also take into account local needs for watering animals, washing clothes, bathing, or other small enterprises--needs which a sectoral agency has no mandate to meet. The result can be improvements in output per unit water, or in equity, or both. Additional advantages of the user-based allocation include, in summary, administrative feasibility and sustainability, and political acceptability.

\section{Disadvantages}

For user-based allocation rules to operate requires a very transparent institutional structure, which may not always be available. Local user-based institutions can be limited in their effectiveness for inter-sectoral allocation of water because they do not include all sectors of users. A village community may readily identify with the needs for domestic use, animals, and irrigation, though the particular interests of different groups within the village (e.g. women's 
greater interests in domestic water, pastoralists in animal supplies, farmers in irrigation) will differ. But industrial demand is often seen as "outside" the local community, and therefore not amenable to user-based allocation.

Even where inter-sectoral competition is not localized, but requires coordinating between municipal and industrial demand in one area, and irrigation in another part, user-based allocation can work through federations of user groups. User associations that include all who hold rights to water from a common source (including agricultural and other uses) are able to negotiate inter-sectoral allocation amongst themselves in Chile. During periods of acute water scarcity, agriculture receives lower priority than urban needs. However, even during the three most severe droughts, agreements were reached in the vast majority of cases because all parties negotiate directly and prefer to "keep the state out" (Rosegrant and Gazmuri 1994).

\section{EXPERIENCE FROM VARIOUS COUNTRIES}

The allocation mechanisms described above have been applied, with some combinations and modifications, to different sectors and locations. In this section we review several interesting cases which provide some lessons to be considered in future implementation of allocation mechanisms.

\section{Marginal Cost Pricing}

Given the long list of disadvantages and difficulties of implementing marginal cost pricing, it is not surprising that there are only few good examples of its strict application to water management in reality.

\section{Irrigation water in France}

In France, water for irrigation is generally sold on the "binomial tariff" basis. (The binomial tariff system accounts for off-peak and on-peak costs). Jean (1980) describes a system in operation since about 1970. The Societe du Canal de Provence et d'amenagement de la Region Provencale supplies water to some 60,000 hectares of farmland. This scheme is thoroughly 
grounded in the theory of marginal cost pricing, with full recognition of the need to consider and reflect long-run costs if farmers are to make "correct" investment decisions in terms of land, cultivation, crops, irrigation equipment and storage (and, indeed, if the Societe itself is to do the same with respect to new water resource works). A peak period is identified lasting for five months from mid-May to mid-September and that plays a central role in the tariff. Tariff design starts from the objective that tariffs should reflect:

- In the peak period, long-run marginal capital costs augmented by operating costs.

- In the off-peak period, operating costs only.

- Possible discharge reduction in the form of pollution fees.

For various practical reasons, this objective sometimes has to be compromised. Thus irrigators "correctly" contribute to the capital costs for their distribution network only through an annual charge based upon the peak demand subscribed for by the user. The development costs of the headworks, which in theory should similarly fall within irrigators' demands in peak periods, are in fact lumped in with operating costs in order to establish a single year-round volumetric charge. This results from "considering the nature of the consumption which is distributed in a well-known way between the peak periods and the off-peak periods, ... [it] simplifies the price scale and enables the use of a single meter reading" (Jean 1980).

For other sectors (e.g., urban, industrial), operating costs constitute the only element in the off-peak volume charge. Off-peak demand thus has no role in determining responsibility for capital cost recovery, precisely as the economic theory of peak demand indicates (see Rees 1984).

However, the French government maintains that the agriculturists relying on the canal are a beneficiary sector and therefore a state subsidy of 50 percent on all elements of the irrigation tariff is granted. At a stroke, the price signals are clouded and the messages altered. Nevertheless, the concept remains intact (Jean 1980).

Although not strictly following marginal cost pricing principles, the use of incentivebased volumetric pricing has been effective in inducing household and industrial use. Following are several examples. 


\section{Household Consumption}

Removal of subsidies in urban water use can have dramatic effects on water use. An increase in the water tariff in Bogor, Indonesia from US\$0.15 to US\$0.42 per cubic meter resulted in a $30 \%$ decrease in household demand for water. It is likely that this degree of price responsiveness is typical for household demand in developing countries, although evidence is limited. A considerable body of analysis for developed countries shows a central range of price elasticities of demand for household water of -0.3 to -0.7 (Frederick 1993). There have been few studies of household demand elasticities in developing countries because water tariffs have generally been low, price changes have not been significant, and metering has been absent. However, the limited available evidence is consistent with the estimated values for developed countries. In urban Brazil and Mexico, estimated price elasticities for urban water demand are -0.60 and -0.38 , respectively (Gomez, 1987).

\section{Industrial Water Use}

Experiences in the U.S. and Japan show that increased water prices, effluent charges, and pollution regulations have great potential to generate industrial water savings by promoting investment in water recycling and water conservation technology. Increased water tariffs induced a $50 \%$ reduction in water use over a 5 -year period by a fertilizer factory in Goa, India. In Sao Paulo, three industries reduced water consumption by $40-60 \%$ in response to establishment of effluent charges. In Israel, water consumption per unit value of industrial output dropped by more than two-thirds from 1962 to 1982 . This was achieved through issuance of restrictive water licenses, introduction of water-saving technologies, and subsidized financing for investment in water-saving processes (Bhatia and Falkenmark, 1993).

\section{Public Water Allocation}

Since public water allocation is long standing and widely practiced, there are several examples for the well rooted public water allocation procedures. 


\section{Bureau of Reclamation and the American West}

In the United States, private groups first invested in major irrigation works in the West in the mid-1800s. Throughout the remainder of the $1800 \mathrm{~s}$ the U.S. government had a small and somewhat peripheral role in Western irrigation development. By the turn of the century, there was a stronger sentiment for some control of large, western rivers but that the costs of such an endeavor were beyond the means of private irrigation companies (Wahl 1989). This led to the passage of the Reclamation Act in 1902 and the creation of an agency that later became the Bureau of Recreation (BuRec). Initially, the BuRec undertook the building, operation and maintenance of dams, reservoirs and canals to support irrigation expansion in the West. Since 1950 the Bureau of Reclamation, responsible for federal development of irrigation, has irrigated between 21 and 25 percent of total irrigated land in seventeen Western states (Wahl 1989).

The structure of allocation and cost-recovery under the BuRec has evolved over time. Since 1906 the BuRec has had authority to allocate water for irrigation, for nearby towns and cities, and for hydroelectric power. However, the BuRec has no rights to water per se. Rather, it has control and management authority of water distribution and storage systems. Furthermore, the BuRec cannot charge water users more than the capital and O\&M costs (Cummings and Nercissiantz 1992).

Public water reclamation for these uses has long been tied to water supply subsidies and the extent of these subsidies has increased over time. These subsidies take two possible forms: interest free repayment schedules, and repayment schedules based upon bureau estimated "ability to pay" (Wahl 1989). As Wahl describes the reclamation subsidy: "What began as a proposal for modest federal assistance in settling the arid West, providing a revolving fund to which costs would be repaid within ten years, evolved into a program that provided major subsidies to irrigation water users--sometimes more than 90 percent of construction costs" (Wahl 1989:38).

These programs require host states to provide around 50 percent of necessary funding and also require that the projects demonstrate benefits beyond private benefits. The federal program resulted in more irrigation in the West. That expansion, however, was not without a cost. While many private investments in irrigation in the West failed, the government continued irrigation subsidies to water users and averted farm failures by extending repayment periods, deferring repayment, and sometimes forgiving repayment altogether (Wahl 1989). At a national 
level, “...extensive water subsidies have led to inefficient use of land and water resources as well as capital, labor and materials." (Wahl 1989: 45). The costs of many subsidy-supported projects sites exceeded benefits. "Consequently, dams have been placed where rivers, in the absence of the irrigation subsidy, would have been left in their natural state. Furthermore, low-cost water has provided little incentive for careful use of the resource. This means that water has been diverted to uses other than those that would produce the greatest economic benefits and has, for the most part, continued to be used for the original purposes." (Wahl 1989).

\section{The PASTEN Mechanism in Indonesia}

The PASTEN system, which is administered by the Provincial Water Resources Srvices with guidance from the Directorate General of Water Resources Development (DgWRD) of the Ministry of Public Works in Indonesia, is a process of determining fixed proportions of water to allocate it across tertiary-level irrigation units (Howe 1990).

The PASTEN allocation mechanism, described in Box 2, takes into account different onfarm canal conveyance and operational losses, it takes into account the different cropping patterns in a simple way that can be adjusted as crop stages change, and it provides a set of computable guidelines for the water management team who must allocate the water by controlling flow rates at various gates. No consideration is given, however, to economic values of different crops, differing productivity of individual tertiary units, and to opportunity costs of water not used in other projects on the river basin. The PASTEN mechanism is incompatible with the efficiency criteria because it sets proportions of water to be applied to each crop based upon the maximum physical yield possible.

\section{Box 2: Principles of the PASTEN Allocation Mechanism.}

The basic design consists of biweekly calculations of the "full water requirement" of each tertiary unit given the crops and their growth rates in each unit. To this amount is added the amount of water that can be expected to be lost before application (terrain, soil type, canal loss). The sum is an estimated "full diversion requirement" (DR) for each unit. The full diversion requirement is compared to the known total water available in the system to estimate a "PASTEN Index," or K value, which is actually a ratio of available water to $D R$. When available water resources at least meet $D R$, the $K$ value is equal to 1 or more. A water shortage means that $\mathrm{K}$ is less than 1 . The allocation of water then is done in fixed proportions across all irrigation units. Proportions allocated are based on the ideal water applications given no scarcity, and the delivery and application losses of each unit.

Source: Howe (1990). 


\section{Water Markets}

Water markets are relatively new in many regions, although in Spain they have functioned for several centuries (Reidinger 1994). One can find variations that include surface water markets, groundwater markets, water auctions, and water banks. In this section we review two case studies from Chile and California that feature variations of the of surface water trade principles.

Water Markets in Chile

Chile's National Water Code of 1981 established a system of water rights that are transferable and independent of land use and ownership. Water rights are defined as permanent (from unexhausted sources) or contingent (from surplus water), and as consumptive or nonconsumptive. Rights can be obtained by petition to the government or they can be established by right based on historical use; they can also, of course, be purchased from the owner. In practice, the historical-based right method has been used the most to establish water rights, because the government's 1966 expropriation of all water rights has necessitated establishment or reestablishment of those rights since the National Water Code was passed.

The most frequent transaction in Chile's water markets is the "renting" of water between neighboring farmers with different water requirements (Gazmuri 1994). This can also be termed a "spot market" in which the owner sells a portion of his or her water, usually over a brief period (perhaps even hours), sometimes without fulfilling formal, legal requirements. Although the volume of sales may not be metered, the buyer and seller have good information on the amount exchanged. Compensation may be in kind or in some other form of monetary or nonmonetary benefit.

The formal buying and selling of water-use rights in Chile requires legal sanction and registration. Although the law defines water use rights as a volume of flow per unit of time (24 liters $/ \mathrm{sec}$ ), in practice rights are a share of stream flows, since variability renders the volumetric/time specification impractical. Use rights are required for groundwater exploitation; these rights prohibit the user from other withdrawals within the area specified in the right. There is a system in place for challenging the granting of water rights and for resolving disputes related to them. 
Prices for water rights are left to the buyers and sellers. In a study covering over 700 shares of water in four river valleys in Chile, Hearne and Easter (1995) found that for both intraand inter-sectoral transactions, "market transfer of water-use rights does produce substantial economic gains-from-trade," in the two valleys were transactions were numerous. In the Elqui Valley, for example, annual net gains from trade were calculated (Hearne and Easter 1995) to be in the range of US\$5.99 and US\$1642.00, with an average of US\$826.00 per share of water traded, depending on the type of trading sectors. In the Limari valley the net gains-from-trade were calculated to be in the range of US $\$ 1.65$ and US $\$ 2.85$ with an average of US\$2.40 per cubic meter. In the Limari Valley 1 share equals, on the average, $4880 \mathrm{~m}^{3} /$ year, so that the average gains from trade in the Limari Valley are US $\$ 11,700$ per share.

\section{Drought Water (Market) Bank in California}

A water bank is an institution that offers to buy and sell water under some set of rules regarding prices and quantities, in a given service area. Water banks can mark up water prices to cover transaction costs and can also use it to compensate the area of origin. There are several examples of efficient and equitable transfer of water by water banks (Howe and Goodman 1995). We will present here the California drought water bank of 1991-92.

After five years of continuous drought, an emergency drought water bank (DWB) was set in California, following appropriate legislation (to allow for transfer of water rightsand minimize environmental degradation). The aim of the DWB was to enable transfer of water from agriculture in northern California to urban, municipal, and agricultural sectors in southern California. The principles of the DWB were:

- Voluntary transfers

- $\quad$ Protection of fish and wildlife

- Protection of ground water basins

- Efficient use of water in receiving areas

- $\quad$ Protection of present water right holders. 
In 1991 , the purchase price by the DWB was set to $\$ 125 /$ acre-foot $^{6}$ and the sale price by the DWB was set to $\$ 175 /$ acre-foot. As a result, more than 300 transactions were recorded. The DWB bought 820,000 acre-feet, and sold 389,952 acre-feet, mainly to urban and industrial users $(32 \%)$, and to agricultural users (16\%). The difference (quantity not sold) was used for the environment ( $20 \%$ of the total) and for recharge ( $32 \%$ of the total), which by itself has an implicit economic social value; a small part was also lost in the system. The value of water purchased by DWB was $\$ 102,500,000$ and the sale value was $\$ 68,241,600$. Direct and indirect effects of the DWB in 1991 were analyzed by Coppock and Kreith (1992) and Howitt et al. (1992) and include increased income in receiving areas. Negative indirect effects were noted on soils, wetlands, and third party effects in the form of unemployment in the selling areas.

\section{Advanced Ground Water Markets in Gujarat India}

There are a variety groundwater market arrangements in India (Shah, 1993; Saleth, 1996). In Gujarat, where water selling is an old tradition, market have become a sophisticated economic institution. The highly advanced water markets in Gujarat differ from elsewhere in South Asia in that (a) farmers invest in modern water extraction mechanisms (e.g., pumps) for selling water which has become a specialized subsidiary occupation, and (b) substantial private investment in underground pipeline networks generate high degree of competition amongst sellers of water. Once one seller establishes a pipeline network, he drives out of business several others who used unlined field canals to convey water to the buyers.

Although the evolution of such "irrigation networks" is not uniform in different parts of Gujarat, agriculturally advanced areas have better developed networks. This type of investment in the water market may have a large multiplier effect. In addition to making the water markets more competitive, investments in conveyance and in water extraction increases efficiency in water and power use.

\section{Latent Water Markets in Cumbum Valley, Periyar-Vaigai Basin, Tamil Nadu}

Field observations made in a village (Royappan Patti located in the Cumbum Valley, Periyar-Vaigai Basin, Madurai district, Tamil Nadu) reveal certain important aspects of groundwater market operation (Dinar and Saleth, 1997). This village like most others in this valley has

\footnotetext{
${ }^{6} 1$ acre foot equales $1235 \mathrm{~m}^{3}$
} 
three farming systems (the canal command with an exclusive focus on paddy, the ground water areas centred on banana, coconut, and grapes, and the rainfed system with mainly groundnuts and redgram (a type of pea) followed by coarse cereals for fodder) running parallel to the Periyar canal between the river and the foothills of the western ghats.

Excellent soil and economic opportunity from high value crops have prompted many private farmers to undertake ground water transfers both from the canal commands as well as from the foothills south of the village where a dam with a capacity of 2.25 million $\mathrm{m}^{3}$ is currently under construction. (Although the water from this dam is planned to be moved $25 \mathrm{~km}$ north of the village by cement lined channel, the water in the dam site will recharge the groundwater aquifer in this region.) Today, there are 10 private groundwater transfer pipelines-4 from the wells in the private farms in the canal command and 6 from the wells located in the private farms on the Shanmuga River banks. All these transfers involve a $12 \mathrm{HP}$ pump of $30 \mathrm{~m}^{3} /$ hour delivery capacity and running on an average 8 hours/day (depending upon power availability per day which is normally limited to 4 hours in the day and 4 hours in the night). Although power cost is zero (due to free electricity for farming in Tamil Nadu), the maintenance and investment costs are very high as each of the water transfer project with an average length of 3 to $4 \mathrm{~km}$ costs anywhere between Rs. 50,000 to 200,000. Each of these transfer project irrigates on an average 20 ha of land either in isolation or in conjunction with local wells (which are very few with marginal water yield).

Since most of the water transfers are used to irrigate the rainfed area close to the foothills, land productivity (and hence, water productivity) has increased tremendously mainly due to crop pattern changes and land use intensity. The lands used earlier for raising crops like groundnut, pulses, and coarse cereals under rainfed condition are now under high value crops like banana, grapes, and coconut. As a result, the additional income per ha has increased 10 to 20 times during the past few years. (While the income/ha from rainfed crops can hardly exceed Rs. 10000/ha/year, the income/ha from grapes and coconut comes to about 100,000 to $200,000 /$ ha/year. ${ }^{7}$ ) More importantly, the intensive year-round cultivation due to groundwater transfers has also increased employment, at least, by three times and reduced seasonality in farm employment. ${ }^{8}$

\footnotetext{
${ }^{7}$ Revenue for grapes $(237,000 \mathrm{Rs}$./ha) is calculated based on $6000 \mathrm{~kg} / \mathrm{season} /$ acre with 2.47 acres per ha, 4 harvests per year and a price of $4 \mathrm{Rs} / \mathrm{kg}$. Revenue for coconuts $(194,400 \mathrm{Rs} . / \mathrm{ha})$ is based on 240 trees per ha, 9 harvests per year totaling 30 nuts/tree/year and a price of 3 Rs./nut. Establishment cost for grapes are $70,000 \mathrm{Rs} / \mathrm{ha}$ and for coconuts $30,000 \mathrm{Rs}$./ha. With lifespan of 20 years, and minimal variable costs, the range of Rs. 100,000-200,000 seems reasonable, and even underestimation of the actual values.

${ }^{8}$ One reviewer raised the question of risk to the high value perrenial crops in the case that the water market collapses. Although this issue is less important with permanent water markets, in the case of latent (supplemental) water market this is probably the reason for such merkets to "wake" in drought or water-
} 
These water transfers initiated by large farmers using mostly their own capital (some farmers have also obtained bank loans) also benefits smaller farms in the vicinity through periodic water markets (i.e., during water scarce time) operating under two arrangements: one involving the sale of water at Rs. 20 /hour and the other involving a somewhat a long-term arrangement. Under the latter arrangement the buyer has to deposit a refundable amount of Rs. 10,000/acre with the seller who, in turn, supplies water in lieu of interest payment (since the monthly interest in the village varies from 2 to 10 per cent, water payment amounts to Rs. 2400 to 1200/acre/year. This higher amount is not a problem as the buyer also grows high value crops like banana.) Notably, since these water marketing activities occur essentially in scarce water periods, they remain latent in periods with better rainfall and water supply conditions.

\section{Transferable Water Entitlements In Australia}

Transferable water entitlements were introduced in several Australian states--in New South Wales, and South Australia in the early 1980s, and in the late 1980s in Queensland and Victoria. Data in Pigram et al. (1992) suggests a positive trend in quantities of water trade in all states over the period 1987-1988. The volumes transferred accounted for $5-10 \%$ of the water use in these states. It should be emphasized that most water transfers were not permanent, but seasonal; of all transaction, 620 were of a temporary nature and 46 were of a permanent nature. Total volume transferred temporarily was 137.3 million $\mathrm{m}^{3}$, and total volume transferred permanently was 19.7 million $\mathrm{m}^{3}$. The data for the New South Wales state, which exists between 1984 and 1991 is summarized in Table 1. From the data it can be seen that annual transfers vary, although the trend is increasing, and the average unit value of water (in nominal Australian \$) vary between 1 cent and 13 cents.

The accumulated experience with the transfer of water among users (mainly water agencies providing water to agricultural farmers) both over time and across regions can shed light on relative importance of potential problems associated with water transfers. Pigram et al. (1992) surveyed the agencies involved in water transfers and the results are presented in Table 2.

The range of potential problems in table 2 may be indication of the set of benefits and concerns associated with the implementation of transferable water rights elsewhere. While some potential problems, such as capacity and water and soil salinity, are associated with the physical

short years than in regular rainy years. In such events available water is transferred from staple to perennial crops. 
characteristics of the regions involved, the other potential problems are associated with the existing economic and social structures of the regional activities. Therefore, these institutions can be generalized conditions prevailing elsewhere. The interested reader may find additional insights to the latter issues in Holden and Thobani (1996).

Table 1: Volumes and Values of Water Transfer Transactions in New South Wals (19841991)

\begin{tabular}{lrrrrrrrr}
\hline Year & 1984 & 1985 & 1986 & 1987 & 1988 & 1989 & 1990 & 1991 \\
$\begin{array}{l}\text { Volumes Trans- } \\
\text { ferred }\left(10^{6} \mathrm{~m}^{3}\right)\end{array}$ & 5.2 & 34.9 & 50.7 & 80.6 & 342.4 & 87.6 & 110.0 & 140.0 \\
$\begin{array}{l}\text { Values of } \\
\text { Transfer }\left(\$ 10^{6}\right)\end{array}$ & 0.7 & 1.8 & 4.8 & 4.7 & 17.0 & 1.1 & 10.5 & 8.0 \\
\hline $\begin{array}{l}\text { Value per Unit } \\
\text { of Water }\left(\$ / \mathrm{m}^{3}\right)\end{array}$ & 0.135 & 0.051 & 0.094 & 0.058 & 0.049 & 0.012 & 0.095 & 0.057 \\
\hline
\end{tabular}

Source: Calculated from Pigram et al. (1992, pg 27, 31)

Table 2: Relative Importance of Potential Problems in Agency Decisions on Transferability Application

Number of Agencies Indicating

Problem Was

Potential Problem

Very Important Not Important Important

Increased load on existing delivery or drainage facilities

Increased soil salinity levels in the area receiving transferred water

$\begin{array}{lll}2 & 1 & 1 \\ 3 & 1 & - \\ 3 & 1 & - \\ - & 1 & 3 \\ 1 & - & 3 \\ - & 1 & 3 \\ - & 2 & 2 \\ - & 2 & 2\end{array}$

Increased water salinity levels in the receiving area

Source: Pigram et al. (1992, pg 20) 


\section{Mixed Systems of Allocation}

\section{California Groundwater}

In Southern California pragmatic, diverse, decentralized, and to a large extent successful approaches to groundwater management have evolved over time as water users and local governments have responded to depletion of groundwater resources and degradation of the environment (Rosegrant, 1995). Groundwater management programs have resulted in elimination of overdrafts, impoundment of surface and imported water for aquifer replenishment, and had stopped saltwater intrusion (Blomquist, 1995).

Four principles govern groundwater rights in California: (1) overlying land owners have rights to the reasonable use of groundwater on their land; (2) relative to each other, overlying land owners have correlative rights to water, and share proportionately in water supply reductions in the event of shortages; (3) appropriators (those pumping water who did not own overlying land) have a seniority system with respect to one another, with reductions in water use imposed first on junior rights holders; and (4) overlying owners have a superior right compared to appropriators to the amount of water for their reasonable use, and appropriators have a right to the surplus remaining, if any (Blomquist 1992).

The California water law also calls for adjudication of groundwater rights among all users in a basin or aquifer when disputes over these rights occurs. Adjudication generally is initiated when one or more rights holder feels that their rights are being impaired due to lowering of water table or contamination of the water. The adjudication process has resulted in a governance structure for the water basin which establishes water rights, monitoring processes, means for sanctioning violations, representative associations of water users, financing mechanisms for the governance system, and procedures for adapting to changing conditions (Blomquist 1992). Central to the governance structures is a water management program which in different basins has employed a variety of the instruments described above (and combinations of instruments) to influence water demand, including pumping quotas (usually based on some notion of historical use), pumping charges, and transferable rights to groundwater.

The key elements which have made these governance structures for groundwater management efficient in many of the basins in Southern California also make them highly appropriate for developing country conditions. Key elements for the success of these governance struc- 
tures are that they are agreed upon and managed by the water users; are responsive to local conditions; operate with available information and data bases, rather than requiring theoretically better but unavailable information; and are adaptive to the evolving environment.

The proper role for government is also suggested by a characteristic that is both a strength and weakness of the establishment of groundwater management procedures in California. Solutions for groundwater management are not imposed, or even considered, unless a management problem exists, thus preventing interventions that can derail efficient utilization of groundwater. The negative side is that the move toward solutions often does not begin until significant damage to the groundwater resource has been done, in large part because of the difficulty in obtaining information about the status of the aquifer. This suggests an important role for government in monitoring and reconnaissance of the groundwater resource to identify emerging problems; and in facilitating an institutional environment that is conducive to decentralized solutions.

\section{User-Based Allocation}

A rich set of examples for user-based allocations can be found in Coward (1980), Ostrom (1992), Ostrom et al. (1994), and Tang (1992). Here we provide only several examples to demonstrate the advantages and disadvantages of this mechanism.

\section{Balinese Subaks in Indonesia}

The Subaks of Bali are one of the strongest examples of user-based allocation. Discovery of the sophistication of these systems provided the basis for some of the early challenges to assumptions that state management of irrigation was necessary (see Coward 1980). These irrigation associations have developed and constructed their own irrigation systems with very little external assistance. The systems have been sustained over time by elaborate management rules and practices that specify obligations of each member in terms of labor and cash contributions for operation and maintenance, including periodic rehabilitation (Geertz 1980). A key feature of the Subaks is the "tektek" principle of proportional water allocation to each individual member. The tektek shares are based on a proportion of flow through diversions structures. There is a strong emphasis on equity, so that allocation takes into account the farmers' role in the association, distance from the intake, initial investment, soil conditions, and transfers of water rights 
among members (Sutawan 1996:3-4). The systems also exhibit a high degree of flexibility and responsiveness to negotiations among members.

Balinese Subaks have several advantages which contribute to their effectiveness, and the sustainability of the institutions for user-based allocation over time. They are grounded in a cohesive social structure that discourages any overt conflict. Migration has been relatively low, which provides users with a longer time horizon to increase the payoffs to cooperation, as well as enabling people to learn how to interact with each other. There is also heavy dependence on irrigated production for household income. The irrigation associations are reinforced by village institutions and religion, with priests playing an active role in allocation.

Subaks are not necessarily limited to irrigation. Pitana (1993) provides a recent case of a locally-developed multipurpose water delivery system in Bali, Indonesia. After a serious drought, a group of 70 villagers in Bunutin identified a water source in another village. They raised $\$ 50,000$ plus local materials and voluntary labor to construct a dam, tunnel, and canal, with the state providing only technical advice. "The villagers voluntarily assisted the group because the water would be used not only by group members, but by all villagers who would have access to it for domestic purposes (Pitana 1993:14)." When water supplies exceeded domestic needs, the remainder was allocated for irrigation in equal shares for all group members. However, the need for continuous flow for domestic use influences the type of water distribution: instead of a timed rotation, each "share" receives a small flow over a proportioning weir.

One characteristic of subaks is their relatively small unit size (usually less than $300 \mathrm{ha}$ ). But federations of subaks can manage water allocation up to the river basin level. Lansing (1991) describes the traditional role of priests and temples in coordinating water flows among subaks. Where new infrastructure is being developed to expand subaks by integrating the intakes of multiple subsystems, there have also been externally-assisted projects to develop federations at two levels: the subak gede (including all subaks that have been integrated into a system with a common permanent weir) and subak agung (including all subaks along one or more river courses--see Sutawan 1996).

\section{Tank Irrigation in India}

The tanks of South India provide a clear illustration of such locally-managed multiple use. Many of these earthen dams and reservoirs, ranging from a few hectares to over a thousand 
hectares, date back hundreds of years. Although their largest consumptive use is for irrigation, the water is also used for bathing, laundry, watering animals, and raising fish and trees. Village panchayats, local temples, or specialized tank associations have traditionally managed the tank resources, deciding such issues as how much water should be released for irrigation or retained for fish, animals, and domestic uses. However, since the colonial period the state has taken on an expanded role in managing the tanks, which have come under the Public Works Department for irrigation, the Fisheries Department for fish, and various other authorities. This has eroded the user-based management institutions, and caused greater problems for inter-agency coordination. A particular example from Tamil Nadu is presented in the next section

\section{WUA Management of the Tank in Vengal Village, Tamil Nadu}

The village Vengal is located about $60 \mathrm{~km}$ north of Madras city. The tank here is one of the 39000 non-system tanks in Tamil Nadu. It has a storage capacity of 1.1 million $\mathrm{m}^{3}$ with a catchment area of $6.79 \mathrm{~km}^{2}$ and a command area of 178.05 hectare.

The tank is the main source of irrigation (and, even, drinking water until recently when the village got drinking water supply through pipes) and the construction of individual wells is discouraged by potential sea water intrusion given the proximity of the village to the Bay of Bengal $(35 \mathrm{~km})$. This hydrogeological condition contributes not only to the substainability of the socioeconomic entity of WUA but also to the success of the institutional aspects including inter-farm and inter-season water allocation mechanisms.

The WUA has a membership of 252 families all owning land in the command-and managed by an Executive Committee. Each of the four main channels that serve the command is operated by a waterman who distributes water to fields in accordance with the guidelines set by the WUA. During the first crop season (September - January) that coincides with the North-Eastern Monsoon, all land in the command receives irrigation. But during the second and third crop seasons, only about 50 and 22 per cent of the command receives irrigation (while paddy dominates the cropping pattern in the first two season, in the third season other less water-intensive crops enters into the cropping pattern). Interestingly, it is an accepted fact that during scarce times, land located closer to the tanks has a priority for water (which, in fact, pre-empts water-sharing conflicts). 
The WUA in Vengal, as far as can be observed (Dinar and Saleth, 1997), has a number of desirable aspects for providing incentive structure not only for farmer's involvement in water management and allocation but also for water use efficiency and conflict resolution. For example, there is an accountability of the irrigators for their performance, rotation of service providers to prevent build-up of vested interest, and rotation in queues of farmers for irrigation water in watershort years.

Financially speaking, the WUA is in the process of collecting Rs.100/ha from the members and applying for the matching grant of Rs.100/ha routed through the Irrigation Management and Training Institute, Tiruchirapalli by the state government. These amounts will be deposited in the nationalised bank in the village in the name of the WUA and interest therein will be used to support the activities of the WUA.

\section{Operational Rules in a Communal Irrigation System in Portugal}

The conversion of water rights into a day-to-day water distribution is a sensitive matter that may transform efficient and fair allocation into inefficient and unfair distribution. Rules developed in Vila Cova--an agricultural communal village--in Portugal (Hoogendam et al., 1996) form the basis of the distribution of water among the users. Issues such as beginning and ending of the irrigation period, losses in canals, travel time of water, user sequence, and night turns, are addressed via various arrangements that involve the community priest, and other community institutions. For example, once it has been decided which user will start the summer irrigation, a clock is put in the window of the priest's house to show the irrigation time and when the flow should be taken from one user to another.

\section{DISCUSSION}

Water has become an increasingly scarce resource that requires careful economic and environmental management. Traditionally, the dominant role of the state in the management of water resources has been rationalized based on the public good characteristic of water. However, inefficient use of the water, low recovery of the operation and maintenance expenses, mounting costs of developing new sources of water, and problems with quality of service in agency- 
managed systems has led to a search for alternatives to increase the efficiency of water allocation and management.

Marginal cost pricing, public, user-based, and market allocation are all found in a wide variety of contexts. No single type of allocation is best for all contexts. The requirements and outcomes of each need to be carefully examined. Based on the principles reviewed in this paper, we suggest the following as key considerations (see also Meinzen-Dick and Mendoza, 1996):

There is an essential role for the state (public allocation) in the development and management of water resources, particularly under circumstances involving large scale systems. The state's interest in many water resource investments relates to their strategic importance, e.g. because of its role in increasing food security or public health. In addition to such positive effects that may not fully be captured by the private users, negative externalities associated with much water use (e.g., downstream pollution) call for a strong regulatory role for the state. However, the resulting public allocation depends on the relative political influence of various stake holders.

User-based allocation is generally more flexible than state allocation, but the high transactions costs for organizing users to develop systems and allocate water over large areas means that this type of allocation is more often found for small-scale systems and the tertiary level of major systems. However, the user organizations needed to provide these services are unlikely to be sustainable unless they also offer their members greater control over water. This means they must have decision-making authority for water allocation, as well as distribution. Such collective action is not likely to be equally effective in all locations. It is most likely to emerge where there is a strong demand for water, and a history of cooperation.

Just as political power of different sectors affects the outcome of public allocation, the local influence of different groups (e.g. women, farmers, pastoralists) will influence user-based allocation patterns. Local social norms also have a major influence. Most societies have some norms giving priority to drinking water as a basic need that should not be denied to anyone-inside or outside the group. Islamic notions of a "right of thirst" for animals also apply in many societies (Wescoat 1995). However, both of these norms are subject to restrictions on users that would ritually or physically pollute the source. In India and Bangladesh, caste purity and pollution restricts the access of low-caste households to water from many sources. They may be 
precluded from bathing or washing clothes or dishes, and even have to depend on high-caste members to draw drinking water for them (Sadeque and Turnquist 1995).

Market allocation has strong advantages in providing incentives for users to seek the highest-value applications for scarce water resources. For the operation of effective water markets, well-defined, quantifiable, and transferable property rights must exist. Market development and the establishment of clear and firm water rights are compatible with continued state involvement and expanded user group participation in water management. In the establishment of tradable water rights and development of water markets, identifying, establishing, and adjudicating water rights; quantifying, monitoring and regulating harmful "third party effects"; and providing the appropriate legal and institutional support remain the government's vital responsibilities. The outcome of market allocation depends on the economic value of water in different uses. This raises legitimate concerns over the equity implications for smallholders and others who may be unable to compete in the market, and therefore lose rights to water. But one of the major advantages of market allocation is that it provides compensation to those who give up water. As industrial, municipal, and environmental demands grow, farmers are likely to lose water to other sectors under public and user-based allocation, as well, and it is not clear that they will be compensated. Moving toward tradable property rights in water may ease the process of inter-sectoral reallocation by compensating the "losers", and creating incentives for efficient water use in all sectors.

In practice, most countries have some combination of water allocation mechanisms. Each allocation mechanism has advantages and disadvantages. Efficiency is an important goal, but the allocation mechanisms that are considered efficient, are often hard to implement, and require supporting infrastructure and institutions, in addition to expensive monitoring and enforcement systems. Therefore, top-level commitment to water allocation that pursues economic efficiency is needed. The expense of monitoring and enforcement of efficient water allocation mechanisms is given as a justification for such commitment. However, the cost of monitoring and enforcement is a real social cost, and when such costs are too high, then it may not be economically efficient to pursue what would otherwise be deemed economically efficient allocation ,methods. ${ }^{9}$ Moreover, if the principles discussed in this paper are to be used, countries should

\footnotetext{
${ }^{9}$ For a comprehensive technical economic discussion and demonstration, see Tsur and Dinar (1997).
} 
make the commitment to developing and supporting the institutions and individuals that will be putting these principles into action. 


\section{REFERENCES}

Bhatia, R. and M. Fallenmark. 1993. Water Resource Policies and the Urban Poor: Innovative Approaches and Policy Imperatives. Washington, D.C.: World Bank.

Biddie , G. C. and R. Steinberg. 1984. Allocation of Joint and Common Costs. Journal of Accounting Literature, 3:1-45.

Blomquist, W.. 1992. Dividing the Waters - Governing Groundwater in Southern California. ICS Press, San Francisco, California.

Blomquist, W.. 1995. Institutions for Managing Groundwater Basins in Southern California. Water Quantity/Quality Management and Conflict Resolution - Institutions, Processes, and Economic Analysis. In: Ariel Dinar and Edna Tusak Loehman (editors). Praeger Publishers, Westport, Connecticut, pp. 43-61.

Coward, E. W. Jr. (ed). 1980. Irrigation and Agricultural Development in Asia: Perspectives from the Social Sciences. Ithaca, NY: Cornell University Press.

Gomez, C. 1987. Experiences in Predicting Willingness to Pay on Welfare Projects in Latin America. Proceedings of Resource Mobilization for Drinking Water and Sanitation in Developing Nations, San Juan, Puerto Rico, May 26-29.

Frederick, K. D. 1986. Scarce Water and Institutional Change. Washington, D. C.: Resources for the Future, pp. 1-19.

Koehler, C. L. 1995. Water rights and the Public Trust Doctrine: Resolution of the Mono Lake controversy. Ecological Law Quarterly 22(3):541-590.

Coppock, R. H. and Kreith, M. (eds.). 1992. California Water Transfers: Gainers and Losers in Two Northern Countries. University of California, Agricultural Issues Center, Water Resources Center, Davis, California.

Coward, E. W., Jr. 1986. Direct or indirect alternatives for irrigation investment and the creation of property. In Irrigation investment, technology and management strategies for development, ed. K. W. Easter, 225-244. Boulder, CO: Westview Press. 
Cummings, R. G. and V. Nercissiantz. 1992. "The Use of Water Pricing as a Means for Enhancing Water Use Efficiency in Irrigation: Case Studies in Mexico and the United States." Natural Resources Journal, 32(4): 731-755.

Cumming R., A. Dinar and D. Olson. 1996. New Evaluation Procedures for a New Generation of Water-Related Projects. World Bank Technical Paper 349, World Bank, Washington, D.C., December.

Dinar, A., and R. Maria Saleth. 1997. Economic Instruments for Efficient Water Allocation: Issues and Options for India. World Bank, Washington, DC.

Free State Province. 1996. Department of Agriculture and Environment, Action Program for Sustainable Livelihoods in the Rural and Peri-urban Economy. February.

Geertz, C. 1980. Organization of the Balinese Subak. Pp 70-90 in E. Walter Coward, Jr. (ed) Irrigation and Agricultural Development in Asia: Perspectives from the Social Sciences. Ithaca, NY: Cornell University Press.

Gazmuri, R. 1994. "Chile's Market-Oriented Water Policy: Institutional Aspects and Achievements." In Le Moigne, G., K. William Easter, Walter J. Ochs and Sandra Giltner (eds), Water Policy and Water Markets, Technical Paper 249. The World Bank, Washington, D.C.

Hearne, R. R. and K. William Easter. 1995. "Water Allocation and Water Markets: An Analysis of Gains-From-Trade in Chile." World Bank Technical Paper Series Number 315, Washington, DC.

Hoogendam, P., A. Van Den Dries, J. Portela, M. Stam, and J. Carvalho. 1996. From Allocation to Distribution: Operational Rules in a Communal Irrigation System in Northern Portugal. in: Diemer, G. and F. P. Huibers (eds.), Crops, People, and Irrigation, Intermediate Technology Publications, London, pp. 101-115.

Holden, P., and M. Thobani. 1995. Tradeable Water Rights: A Property Rights Approach to Improving Water Use and Promoting Investment, Cuadernos de Economia, 97, December.

Howe, C. W., Schurmeier, D. R., and Shaw, W. D. Jr. 1986. Innovative Approaches to Water Allocation: The Potential for Water Markets. Water Resources Research, 22(4):439-445. 
Howe, C. W. 1990. Equity Versus Efficiency in Indonesian Irrigation: An Economic Evaluation of the Pasten Method. In Sampath R. K. and Young R. A. (eds.), Social, Economic, and Institutional Issues in Third World Irrigation Management. Westview, Boulder.

Howe, C. W. and Goodman, D. J. 1995. Resolving Water Transfer Conflicts Through Changes in Water Market Process. In Dinar, A. and Loehman, E. T. (eds.), Water Quantity/Quality Management and Conflict Resolution, Institutions, Processes, and Economic Analyses. Preager, Westport, Connecticut, pp. 119-129.

Howitt, R. E., Moore, N. and Smith R. T. 1992. A Retrospective on California's 1991 Emergency Drought Water Bank. A Report prepared for the California Department of Water Resources, Sacramento, CA.

Jean, M. 1980. L'application de la theorie du cout marginal au tarif de vente d'eau dans un ouvrage a buts multiples (paper transmitted to the UN Economic Commission for Europe Seminar on Economic Instruments for Rational Utilization of Water Resources at Veldhoven, October 1980, mimeo. Cited in OECD (1987).

Lansing, J. S. 1991. Priests and programmers: Technologies of Power in the Engineered Landscape of Bali. Princeton, N.J., Princeton University Press.

Meinzen-Dick, R., and M. Mendoza. 1996. Alternative Water Allocation Mechanisms Indian and International Experiences. Economic and Political Weekly, XXXI:A25-A30, March 30.

Meinzen-Dick, R., M. Mendoza, L. Sadoulet, G. Abiad-Shields, and A. Subramanian. 1997. Sustainable Water User Associations: Lessons from a Literature Review. In: Subramanian, A., N. V. Jagannathan, and R. Meinzen-Dick, User Organization for Sustainable Water Services, World Bank Technical Paper No. 354, World Bank, Washington D.C.

Moench, M. 1995. Allocating the common heritage: Debates over water rights and governance structures in India. National Heritage Institute, San Francisco (mimeo).

Ostrom, E. 1992. Crafting Institutions for Self-Governing Irrigation Systems. ICS Press, San Francisco, California.

Ostrom, E., R. Gardner, and J. Walker. 1994. Rules, Games, and Common-Pool Resources. The University of Michigan Press, Ann Arbor, Michigan. 
OECD. (1987). Pricing of Water Services. Paris, France, OECD. Rees, R. 1984. Public Enterprise Economics. Second edition. London: Weidenfeld \& Nicolson.

Pigram, J. J., Robert J. Delforce, Michelle L. Cowell, Vol Norris, George Anthony, Raymond L. Anderson, and Warren F. Musgrave 1992. Transferable Water Entitlements in Australia. Centre for Water Policy Research, University of Armidale, Australia.

Population Action International. 1995. Update to Appendix 3 of the 1993 Report Sustaining Water: Population and the Future of Renewable Water Supplies. Washington, DC, 1993.

Phelps, C. N. Moore, and M. Graubard. 1978. Efficient Water Use in California: Water Rights, Water Districts and Water Transfers. The Rand Corporation. Santa Monica, CA.

Pitana, I. G. 1993. Performance indicators: A case of a newly developed FMIS in Bali, Indonesia. In Performance measurement in farmer-managed irrigation systems. Proceedings of an international workshop of the farmer- managed irrigation systems network, ed. $\mathrm{S}$. Manor and J. Chambouleyron, 13-. Colombo, Sri Lanka: International Irrigation Management Institute.

Randall, A. 1981. "Property Entitlements and Pricing Policies for a Maturing Water Economy." Australian Journal of Agricultural Economics, 25:195-212.

Randall, C. 1994. "Water Markets, Market Reform and the Urban Poor: Results from Jakarta, Indonesia. World Development, 22(1): 71-83.

Rees, R. 1984. Public Enterprise Economics. Second edition. London: Weidenfeld \& Nicolson. Reidinger, R. 1994. “Observations on Water Markets for Irrigation Systems.” In: Le Moigne, G., K. William Easter, Walter J. Ochs and Sandra Giltner (eds), Water Policy and Water Markets, Technical Paper 249. The World Bank, Washington, D.C.

Republic of South Africa, Department of Water Affairs and Forestry. 1996. Discussion Document: Water Law Principles. South Africa.

Rosegrant, M.W. 1995. Water resources in the 21 st Century: Increasing scarcity, declining quality, and implications for action. Paper presented at the Conference on the Sustainable Future of the Global System, Tokyo, October 15-18. 
Rosegrant, M. W. and R. Gazmuri Schleyer. 1994. Tradable water rights: Experiences in reforming water allocation policy. Arlington, Virginia: Irrigation Support Project for Asia and the Near East (ISPAN), United States Agency for International Development.

Rosegrant, M.W. and H.P. Binswanger. 1994. "Markets in tradable water rights: Potential for efficiency gains in developing-country water resource allocation." World Development 22 (11): 1613-1625.

Sadeque, S. Z. and S. Turnquist. 1995. Handpump financing issues in Bangladesh: An exploratory study. UNDP/World Bank Water and Sanitation Program, New Delhi (mimeo).

Saleth, R. Maria. 1996. Water Institutions in India. Comonwelth Publishers, New Delhi.

Saleth, R. Maria. 1997. Water Markets in India: Economic and Instiututional Aspects. In: Easter, K. W., M. Rosegrant, and A. Dinar, Markets for Water-Potential and Performance. (Forthcoming)

Saunders, R., Warford, J. J., Mann, P. C. 1977. Alternative Concepts of Marginal Cost of Public Utility Pricing: Problems of Application in the Water Supply Sector. World Bank Staff Working Paper No. 259. Washington, DC: World Bank.

Sutawan, N. 1996. Negotiation of Water Allocation amongst Irrigator's Associations: A Note from Bali, Indonesia. Paper presented at International Association for the Study of Common Property meetings, Berkeley CA, June 5-8.

Shah, T. 1993. Groundwater Market and Irrigation Development: Political Economy and Practical Policy. Bombay, Oxford University Press.

Spulber, N. and A. Sabbaghi. 1994. Economics of Water Resources. Kluwer Academic Publishers, Norwell, Massachusetts.

Tang, S. Y. 1992. Institutions and Collective Action, Self-Governance in Irrigation. ICS Press, San Francisco, California.

Tsur, Y. and A. Dinar. 1997. The relative Efficiency and Implementation Cost s of Alternative Methods for Pricing Irrigation Water. The World Bank Economic Review, 11(2).

Tietenberg, T. H. 1988. Environmental and Resource Economics. Scot, Foresman and Company, Boston, Massachusetts. 
United Nations. 1980. "Efficiency and Distributional Equity in the Use and Treatment of Water: Guidelines for Pricing and Regulations" Natural Resources/Water Series No. 8. United Nations: New York, NY.

UNDP (United Nations Development Program). 1994. Statements and Recommendations from Major International Meetings on Water Resources, Water Supply and Sanitation. New York.

Water Law Review Panel. 1996. Fundamental principles and objectives for a new water law in South Africa. Report to the Minister of Water Affairs and Forestry. Johannesburg.

Watson, G. et. al. 1994. Water and sanitation associations: review and best practice. Paper prepared for World Bank Water Resources Seminar, Lansdowne, VA, December 13-15.

Wescoat, J. L. 1995. The 'right of thirst' for animals in Islamic law: A comparative approach. Environment and Planning D: Society and Space 13:637-654.

Winpenny, J. 1994. Managing Water as an Economic Resource. Routledge, London.

Wahl, R. W. 1989. Markets for Federal Water. Resources For the Future, Washington, DC.

Water Law Review Panel. Fundamental principles and objectives for a new water law in South Africa. Report to the Minister of Water Affairs and Forestry. Johannesburg, 1996.

World Bank. 1993. Water Resources Management, A World Bank Policy Paper. World Bank, Washington, DC.

World Bank. 1996. Staff Appraisal Report (Green Cover), Pakistan National Drainage Program Project, Report No. 16310-PAK, December 23, World Bank, Washington, D.C.

Yoder R. 1981. Non-Agricultural uses of irrigation systems: Past experience and implications for planning and design. Paper prepared for Agricultural Development Council. Cornell University (mimeo).

1994. Locally managed irrigation systems: essential tasks and implications for assistance, management transfer and turnover programs. Colombo: International Irrigation Management Institute. 


\section{Policy Research Working Paper Series}

\section{Title}

WPS 1760 Credibility of Rules and Economic Growth: Evidence from a Worldwide Survey of the Private Sector

WPS1761 Bending the Rules Discietionary Pollution Control in Crina

\section{Author}

Aymo Eruneti:

Gregon Kisunt:

Beatrice Wode

Susmita Desguga a

Mainut tiua

David Whet:ar

Paul J veriet

leffreys Haino?
WPS1762 Strategies for Pricing Pubicly Frovided Health Services
WPS1763 China and the Multilaterai investment Yustuj Feng Guarantee Agency

WPS1764 A Reversal of Fortune for Korean Women: Explaining '983's Upward Turn in Relative Earrings

WPS1765 Explaining Agricultural and Agrarian Policies in Developing countries

WPS1766 New Systems for Old Age Security Theory, Practice, ont Empirical Evidence

\section{Yaba vab der Ne: Keb Rodgers}

Hans P Binswan!jer

riaus Deininger

Estelle James

Estelle jemes

WPS1767 Pension Reform is There a Tradeoff between Efficiency and Equat?

WPS1768 Is There a Quantiry-Quanty Tradeofi as Enrollments Increase? Evidence from Tamil Nadu, hodia

WPS1769 Information, Incentives, and Commitment: An Empiical An ysi of Contracts betwetr Govemmen and State Enterpises

WPS1770 Poverty and Socia! Transfers in Hungary

WPS1771 Government Employment and Pav: A Global and Regional pespecive

WPS1772 What Drives Deforestation in the Brazilian Amazon? Evidence from Satelite and Socioeron.s.
F Durais amy Esieile James Juila Lanit: dee-Peng Tan

Narty M Shirley

i $C_{i n d}$

Cormstigan Groutex:

May $199 \%$

Solvatore Schiavo Jampo May 1997

Giutlo de ommas

Afritha furlers?

Alexaner S P. Piff

May 1997
Contact for paper

M. Geller 31393

$E$ de Castro 89121

May 1997

May 1997

May 1997

May 1997

D. Housden 36637

S. Khan 33651

S. Khan 33651

S. Khan 33651

P. Sintim-Aboagye 38526

G. Ochieng 31123

A. Panton 85433

A. M. Maranon 39074 


\section{Policy Research Working Paper Series}

\section{Title}

WPS1773 The Costs and Benefits of Reguiation: Implications for Developing Countries

WPS1774 The Demand for Base Money and the Sustainability of Public Debt

WPS1775 Can High-Inflation Developing Countries Escape Absolute Poverty?

WPS1776 From Prices to Incomes. Agricultural Subsidization Without Protection?

WPS1777 Aid Policies, and Growth

WPS1778 How Government Policies Affect the Relationship between Polish and World Wheat Prices

WPS1779 Water Allocation Mechanisms: Principles and Examples
Author

J. Luis Guasch

Robert W. Hahn

Valeriano F Garcia

Martin Ravallicn

John Baffes

Jacob Meermar:

Craig Burnside

David Collar

Szczepan Figie!

Tom Scott

Panos Varangis

Ariel Dinar

Mark W Rosegrant

Ruth Meinzen-Dick

June 1997
June 1997

Contact

Date

for paper

June 1997

J. Troncoso

38606

J. Forgues

39774

June 1997

P. Sader 33902

June 1997

P. Kokila 33716

K. Labrie 31001

June 1997

J. Jacobson 33710

June 1997

M. Rigaud 30344 